(Journal of Literary Criticism)

ISSN: 2602-46i6

Cilt IV, Sayı I, Mart 2020

YÜKLENME TARİHI: 02.03.2020 KABUL TARİHI: I7.03.2020 YAYIN TARİHİ: 23.03.2020

Künye: (Araştırma Makalesi) Karabulut, Mustafa - Bulut, Esma (2020). "Roman Tekniği Bakımından Cengiz Aytmatov’un “Elveda Gülsarı” Romanı”, Edebî Eleştiri Dergisi, c. 4/1, s. 97-118 DOI: $10.31465 /$ eeder.697484

\author{
Mustafa KARABULUT \\ Prof. Dr., Adiyaman Üniversitesi, Fen- \\ Edebiyat Fakültesi, Türk Dili ve \\ Edebiyatı Bölümü, \\ mkarabulut@adiyaman.edu.tr \\ ORCID: 0000-0001-6259-0868
}

\section{Esma BULUT}

Yüksek Lisans Öğrencisi, Adıyaman Üniversitesi, Sosyal Bilimler Enstitüsü, Türk Dili ve Edebiyatı Anabilim Dalı esmablt02@gmail.com ORCID: 0000-0003-1412-3944

\section{ÖZ}

Kırgız asıllı Cengiz Törekuloviç Aytmatov; hikâye, roman ve tiyatro türünde yazdığı eserlerle hem Kırgız edebiyatında hem de Türk dünyası edebiyatında önemli bir yere sahiptir. Romanlarında millî unsurlardan beslenerek evrensel bir düşünce biçimini ortaya koyan Aytmatov, Elveda Gülsarı adlı romanına da bunu yansıtır. Romanlarının birçoğunda alegorik anlatıma yer veren yazar, bu anlatım biçimini Elveda Gülsarı romanında bir "at" olan Gülsarı aracılığıyla dikkatlere sunmuştur. Yazar söylemek istediği birçok hususu Gülsarı'nın şahsında verir. Bu romanda savaş sonrası bir toplumda yaşanan ekonomik, sosyal, psikolojik durumları, rejimin baskılarını, değişen yaşam koşullarını, unutulmaya yüz tutmuş değerleri; dostluk, aşk, savaş, özgürlük ve tabiat vb. temaları işlenmiştir. Bu roman daha çok, dolaylı da olsa rejime karşı yapılan bir 'sistem eleştirisi'dir. $\mathrm{Bu}$ çalışmada amaç Cengiz Aytmatov'un Elveda Gülsarı adlı eserini roman tekniği bakımından incelemektir. Bu bağlamda bu roman; olay örgüsü, konu ve tematik düzlem, kişiler, mekân, zaman, bakış açısı ve anlatıcı bakımından ele alındi.

Anahtar Kelimeler: Cengiz Aytmatov, Elveda Gülsarı, roman tekniği.

\section{ROMAN TEKNİĞİ BAKIMINDAN \\ CENGIZ AYTMATOV'UN “ELVEDA GÜLSARI" ROMANI}

\author{
CENGIZZ AYTMATOV'S NOVEL \\ "ELVEDA GÜLSARI" IN TERMS \\ OF \\ NOVEL TECHNIQUE
}

\begin{abstract}
Cengiz Törekulovic Aytmatov, who is of Kyrgyz origin, has an important place in both Kyrgyz literature and Turkish world literature with his works in stories, novels and theaters. Aytmatov reveals a universal way of thinking by feeding on national elements in his novels and reflects this in his novel Elveda Gülsarı.The author, who includes an allegorical narrative in many of his novels, presented this form of attention to attention through Gülsarı, a "horse" in his novel Elveda Gülsarı. The author gives many points to the person who Gülsarı wants to say. In this novel, economic, social, psychological situations, regime pressures, changing living conditions, values that have been forgotten, friendship, love, war, freedom and nature, etc. in a post-war society. themes are embroidered. This novel is rather a "system criticism" against the regime, albeit indirectly. The aim of this study is to examine Cengiz Aytmatov's book Elveda Gülsarı in terms of novel technique. In this context, this novel; plot, subject and thematic plane were handled in terms of people, place, time, perspective and narrator.
\end{abstract}

Keywords: Cengiz Aytmatov, Elveda Gülsarı, novel technique.

\title{
GíRiş
}

Geçmişte yaşanan olumlu ya da olumsuz olaylar bir tecrübe mahiyetini alır. Edebi bir tür olan roman da yazarın yaşadığı toplumsal, sosyal vb. durumlardan etkilenerek düşünce dünyasını oluşturduğu ya da yansıttığı bir platformdur. "Roman, insana ait bir dünyanın yeni bir kurgusu, yeniden yapılandırılmasıdır, bu yeni 
yapılandırma insanlara mesaj vermek içindir. İnsanlığa yaratandan (Allah, God) gelen mesajlar da semavi kitaplarda birtakım örnek kıssalarla anlatıldığına göre narration (tahkiye); bir öğretim, eğitim ve bilinçlendirme aracıdır." (Tural, 2009: 78). Cengiz Aytmatov'un ilk kez "Kopar Zincirlerini Gülsarı" adıyla çevrilen Elveda Gülsarı romanı, 1963'te yayımlanır. Yazarın Toprak Ana, Beyaz Gemi ve Cemile adlı eserleri gibi Elveda Gülsarl da sahnelenen eserler arasında yer alır. Bu eser, Tanabay ve onun gibi devrime inanmış gençlerin II. Dünya Savaşı sonrası yeniden yeşeren ümitlerinin kırıldığı zorlu hayat şartlarının olumsuz etkilerinin yaşandığı bir romandır. "Elveda Gülsarı toplumsal dönüşümler doğrultusunda daha iyi bir gelecek beklentisine sahipken hayal kırıklığı yaşayan insanların romanıdır." (Kaplan, 2009: 306). Roman; gelenekle yeniliğin, geçmiş/eski ile geleceğin/yeninin, özgürlükle esaretin, emekle sömürünün, doğrulukla yalanın, insan gücüyle makine gücünün, toplumsallaşmayla bireyselleşmenin çatıştığı değerler üzerine kuruludur. Roman Gülsarı'nın koşulandığı arabanın tekerleğinin dönmesiyle başlar, tekerleğin dönüş hızının azalıp durmasıyla da sona erer. Romanda tekerleğin dönüşü Gülsarı'nın yaşamını sürdürmesiyle koşut bir şekilde yer alır. Tekerlek dönmeye devam ettikçe Gülsarı da yaşamaya devam eder, tekerlek dönüşünü kaybedince Gülsarı yaşamını yitirir, Gülsarı'nın ölümüyle roman da sona erer.

\section{Olay Örgüsü}

Anlatma esasına bağlı edebi türlerde "olay örgüsü" kuşkusuz asıl unsurdur ve olaysız hiçbir edebi türün varlığı da bu anlamda söz konusu değildir. Çünkü romanın diğer unsurları olan kişi, zaman, mekân gibi hususlar da tamamıyla “olay örgüsü”nün etrafında şekillenir. Bu her roman için geçerlidir. Dikkat edilmesi gereken bir husus "olay" kavramının anlamındadır. Olay sebepsiz olmayan, tesadüfen gerçekleşmeyen şeylerdir. "Nasıl halkaları birbirine bağlayarak istediğimiz uzunlukta bir zincir oluşturabiliyorsak, olaylar da sebep-sonuç ilişkisi içinde birbirine bağlanarak olay örgüsü veya vak'a zincirini oluştururlar" (Çetişli, 2004: 59). Bahsedilen vaka zincirleri hep birbirinden doğan ya da birbirinin sebebi konumundaki vaka parçacıklarıdır. Anlatma esasına bağlı türlerden biri olan roman tahkiye esasına dayanır. Elveda Gülsarı adlı roman da bu esasa bağlı olarak yazılmıştır. Adı mezkûr romanda olay örgüsü çok zincirli olay örgüsü tarzında ele alınmıştır. Çok zincirli olay örgüsü ise birden fazla olaydan müteşekkil bir yapıya sahiptir. Yani çok sayıda olayın birbiriyle bağlantılı bir şekilde kronolojiye riayet edilerek ana olayın etrafındaki gelişmelerin, yeni veya birbirinin devamı olan vakaların verildiği olay örgüsüdür.

Elveda Gülsarı, olay örgüsü bakımından üç bölüm ve bir değerler tablosundan müteşekkildir. Birinci bölüm roman başkişisi Tanabay ve Gülsarı'nın tasviriyle başlar. Bu bölüm romanın en son bölümünü ihtiva eder. İkinci bölümde Tanabay'ın hayat1, Orta Asya Türk gelenekleri ve kolhoz sistemi hakkında bilgiler verilir. Üçüncü bölümde ise Tanabay'ın en yakın arkadaşı Çora'nın, sevgili atı Gülsarı'nın ölümü ve kolhozun işlevsizliği anlatılır.

Romanda olaylar gözlemci/müşahit bakış açısıyla anlatılmıştır. Meydana gelen olaylar gerçekçi biçimde verilmiş, olaylara doğrudan bir müdahalede bulunulmamıştır. Elveda Gülsarı'da olaylar romanın başkahramanı Tanabay'ın partiden ihraç edildiği ve en yakın dostu Çora'nın öldüğü gün, uzun zamandan beri göremediği sarı atılla eve dönerken atının ölmek üzere olduğu bir yolda 
(Aleksandrovka yokuşu) geçmişini hatırlamasıyla başlar. Bu tasvirde Tanabay'ın ve Gülsarı'nın yaşlanmış vaziyette verilmiştir:

"Yaşlı adam kırık-dökük bir arabaya binmiş geliyordu. Arabayı çeken taypalma yorga ${ }^{1}$ Gülsarı da çok yaşlı ve bitkindi. Bir deri bir kemik kalmıştır" (s.7). ${ }^{2}$

Anlatıcı-yazar burada kişileri tanıtmamış sadece onlarla ilgili ilk izlenimlerini dile getirmiştir:

"Önlerindeki yokuş yol, açılmış ince bir bağırsak gibi, tâ belin oraya kadar uzanıyordu. İşte bu engin, çıplak ve issız bozkırda, kış günleri bora, kasırga eksik olmaz, yaz günlerinde ise cehennem sıcağı ortalığı yakar kavururdu. Bu dik yokuşu ağır ağır çıkmak, Tanabay'ın pek gücüne giderdi. Hiç sevmezdi yavaş yürümeyi. Yavaş yürümek bir işkence idi onun için. Gençliğinde ilçe parti komitesi toplantılarına katıldığı günlerin dönüşünde, bu yokuşa geldiği zaman, kamçıyı basar, atını dörtnala sürerdi” (s.7).

Burada anlatıc1-yazar mekânı yanı geniş bozkırı kötümser bir bakış açısıyla irdeler; kış ve yaz mevsimleri de aynı şekilde olumsuz özellikleriyle yansıtır. Nitekim kış için "bora, kasırga", yaz için de "cehennem sıcağı" ifadeleri kullanılmıştır. Bu tasvirlerde realiteye riayet edilmiştir. Öyle ki romanda olayların geçtiği mekân olan Kırgızistan'da iklim gerçekten de yazları sıcak ve kurak, kışları ise son derece soğuk ve karlıdır. Bu olumsuz tasvirleri daha çok romanın birinci ve ikinci bölümlerinde olmak üzere pek çok yerde de görmek mümkündür. Elveda Gülsarı toplamda 25 bölüm halinde yazılmıştır. Ancak bu yazıda romandaki 25 bölüm, olayların başlangıç ve bitiş noktaları dikkate alınarak üç ana bölüm olarak ele alınd.

\section{Bölüm}

Romanın ilk bölümü Tanabay ve Gülsarı'nın yaşlanma süreçlerini anlatan tasvirlerle başlar. Roman geriye dönüş tekniğiyle yazıldığından eserde geriye dönüşler s1k sık görülmektedir. Öyle ki Tanabay tekrar yaşlı sarı yorganın ölmeden önce son kez geçtiği yer olan Aleksandrovka yokuşundadır. Tanabay da Gülsarı gibi yaşlanmıştır. Tanabay ölmek üzere olan Gülsarı'nın başında beklerken sık sık eski günleri, gençlik dönemini hatırlar. Aynı zamanda Gülsarı'nın yaşlanmadan önceki halini, beraber geçirdikleri o mutlu günlerini, arkadaşlarını, can dostu Çora'yı ve başından geçen her olayı bir bir zihninden geçirir.

"Tanabay yürürken sarı yorga ile ilgili uzak geçmişi, olayları, arkadaşlarını bir bir hatıllıyordu: 'Hepimiz böyleyiz işte' diye düşünüyordu. Birbirimizden pek farkımız yok. Ancak ağır hastalandığımız ya da öldügümüz zaman hatırlıyoruz birbirimizi. O yitirdiğimizin ne iyi, ne eşsiz bir insan olduğunu, ne büyük iyilikler yaptığını, ancak o son demde anlıyoruz. İşte Gülsarı da ağzı var, dili yok bir havyan! Onu kim düşünüp hatırlayacak? Kimleri taşımadı sırtında, kimleri gururlandırmadı? Ama yaşlanıp bu hale gelince herkes unuttu onu. Şu haline bak zavallının... Ah o eski günler ah! Ne eşi bulunmaz bir yorga idi o !" (s. 38-39)

\footnotetext{
${ }^{1}$ Taypalma yorga: "Taypalma yorga" ve "Su yorga" dörtnala koşmasını bilmeyen ama dörtnala giden yarış atlarını geçen, güzel yürüyüşlü, hızlı, binicisini hiç sarsmayan, su gibi akıp giden uzun mesafe koşusunda eşsiz bir at cinsidir (çevirenin notu).

${ }^{2}$ Romandan alıntılar için bkz. Cengiz Aytmatov, Elveda Gülsarı, Ötüken Yayınları, İstanbul 2019.
} 
Roman başkişisi Tanabay özellikle Gülsarı ile ilgili anılarını hatırlar ve bu hatıraları düşündükçe üzülür:

“Tanabay bu uzun yol üzerinde, bir zamanlar Gülsarı'ya binmiş olarak ve tozu dumana katarak gittiği günleri hatırlayınca, dudaklarında acı bir gülümseme belirdi. Yorganın geçtiği bu yolda, gerilerinde kuyruklu yıldızın kuyruğu gibi ince, uzun bir toz bulutu bırakırlardı. Bunu uzaktan görenler de, Tanabay'ın Gülsarı ile o yolda gitmekte olduğunu hemen anlarlardı. Hava rüzgârlı değilse, Gülsarı'nın toynaklarından çıkan o toz izi, tepkili uçağın gerisinden çıkan gaz çizgisi gibi uzun süre havada asılı kalırdı. O zaman, yakınlarında olan bir çoban, elini alnına götürüp gözüne siper yapar, yola bakarak 'Aa, bu Gülsarı'dır, başkası olamaz!' derdi ve onun sırtındaki adama imrenirdi. O talihli adamın yerinde olmak isterdi. Böyle bir ata binmek, bir Kırgız genci için gerçekten büyük mutluluk sayılırdı" (s. 39-40).

Görüldüğü üzere geçmişi hatırlamak acı vermekten başka bir şey vermemiştir Tanabay'a. Çıktıkları bu yokuş yol bozuk ve eskidir, tıpkı Tanabay'ın ve Gülsarı'nın eskimiş, yaşlanmış bedeni gibi. Roman Gülsarı'nın ölmek üzere oluşunu anlatan tasvirlerle devam eder. Tanabay, taypalma yorga Gülsarı'nın, Aleksandrovka yokuşunu son defa tırmanmakta olduğunu, atın son adımlarını atmakta olduğunu tahmin edemez.

\section{V: Vaka Halkası}

V1: Yaşlı Tanabay ve yaşlı at Gülsarı'nın dar ve uzun bir yol olan Aleksandrovka yokuşundan evine gitmeleri.

V2: Tanabay'ın sürekli geçmişi düşünmesi, geçmişiyle bir hesaplaşmaya girmesi.

V3: Tanabay'ın oğlunun evine gitmesi ve orada gelininin kendisini azarlamasıyla vakitsizce yola düşmesi.

V4: Tanabay'ın savaştan sonra yurduna dönüp evlenmesi ve çocuklarının doğması.

V5: Tanabay'ın demirciliği bırakıp can dostu Çora'nın isteğiyle zor bir iş olan (at bakıcılığına) başlaması.

V6:Turgay'ın Tanabay'a Gülsarı'yı tanıtması ve onun hakkında bilgiler vermesi.

V7: Tanabay'ın Gülsarı'nın ağzına gem vurması, sırtına eyer geçirmesi.

V8: Tanabay'ın Gülsarı'yla son kez Aleksandrovka yokuşundan geçmesi.

V9: Tanabay'ın geçmişiyle hesaplaşması.

\section{Bölüm}

Bu bölüm "Gülsarı'nın terbiye edildiği yıl yılkılar yaylada her zamankinden fazla kaldılar" diye başlar. Romanda asıl olayın/olayların şekillenmeye başladığ 1 bölüm bu sayfalardan itibaren verilir. Tanabay, romandaki birçok kışı gibi devrime inanmış bir Kırgız-Türk gencidir. Tanabay, savaştan döndükten sonra boş durmamış, gençliğinde uğraştığ 1 bir iş olan demircilik işinde çalışmıştır. Ancak hem kolhoz başkanı hem de en yakın arkadaşı olan Çora'nın 1srarı üzerine yılkıcılık yapmaya başlamıştır. Kolhoz, Rusya'da köylülerin birlikte üretim yaptıkları tarım işletmelerine verilen 1sımdır. Bu sistemde kimsenin mülkiyet hakkı yoktur, üretilen tüm ürünler kolhoza verilir. Bundan ancak kışı kendisine yetecek kadarını alabilir. 
Tanabay için bu dönem savaştan sonra geçirdiği en güzel dönemdir. Çünkü kendisine yoldaşlık edecek ve en önemlisi de kendisini anlayacak özel mi özel bir cins ata sahiplik etmektedir. Tanabay Gülsarı'ya özel bir sevgi besler. Diğer hayvanlara karşı da çok iyimser, merhametli davranır. Ancak Gülsarı onun için başkadır:

“Tanabay'ın savaştan sonra geçirdiği en güzel dönem belki o yıldı. Saçısakalı ağardıktan sonra bir kır ata benzeyecek, yaşlılık dönemine girecekti. Genç yorga onun hayatına iki-üç yıl daha geç girmiş olsayd1, o erkeklik gururunu pek tatmin edemeyecekti. Altında Gülsarı gibi bir yorga olunca, el aleme gösteriş yapmaktan da kendini alamıyordu. Böyle bir yorgaya binmenin gösteriş yapmaması da biraz zordu doğrusu. Hele dağdan köye gitmek için tarlaların arasından geçerken, çalışmaya giden kadınlarla karşılaşınca, eyerin üzerinde daha da dikleşir, yüreği coşkuyla dolardı. Onun bu coşkusunu sezen Gülsarı da daha bir alımlı-çalımlı yürümeye başlardı" (s. 43-44).

Romanda en çok Gülsarı'dan bahsediliyor gibi görülse de asıl olay, Tanabay ve Tanabay gibi devrime inanmış Kırgız gençlerinin çile dolu zorlu hayatıdır. Bu zorluk gerek iklim şartlarının yaşamaya elverişli olmamasından gerek kötü çalışma koşullarından kaynaklanmaktadır. Bu bölümdeki vaka halkaları şöyledir:

V1: Tanabay'ın köy denetim kuruluna üye seçilmesi.

V2: Tanabay'ın evli olduğu halde Bibican'la yasak bir ilişki yaşaması.

V3: Kolhozda işlerin yolunda gitmemesi.

V4: Orta Asya Türk geleneklerinden "kökpar", "cirit", "güreş" gibi oyunların düzenlenmesi ve Gülsarı'nın kökpar gibi at üstünde oynanan yarışlardan birinci çıkarak ününün yayılması.

V5: Havanın bozulması ve Gülsarı'nın yılkıyı merak edip köye doğru hızla gitmesi.

V6: Tanabay'in Caydar tarafindan uyarılması ve Tanabay'in hatasını anlaması.

V7: At çiftliğinin yeni başkanı İbrahim'in kolhoz başkanın emriyle Gülsarı'yı almasi.

V8: Gülsarı'nın defalarca kolhozdan kaçması sonucu iğdiş edilmesi, ayaklarına zincir kösteklerin geçirilmesi ve at korasına hapsedilmesi.

V9: Toplumsal değerlerin yitirilişi.

Kolhozun işleri yolunda gitmemeye başlamıştır. Tanabay bu bölümde köy denetim kuruluna üye seçilmiş bu yüzden de sık sık köye gidip gelmektedir. Tanabay, köye giderken çok heyecanlanıyordu. Çünkü sevdiği kadın Bibican bu köyde oturuyordu. Kolhozda işlerin yolunda gitmemesinden dolayı muhasebeciyle tartışan Tanabay kolhozdaki sıkıntıları halka izah edemeyeceğini düşünerek kızar, üzülür. Tanabay, rejime son derece bağlıdır, onun için canla başla çalışmış hatta öz ağabeyini dahi bu uğurda Sibirya'ya sürdürmüştür. Oysa Kulıbay kendi emeğiyle elde etmişti her şeyi:

"Bunlardan biri ağabeyi Kulıbay idi. Sibirya'ya sürülmüş ve savaşa kadar yedi yıl orada kalmıştı" (s. 47). 
Romanda Tanabay'ın kardeşi ile ilgili olarak şunlar söylenmiştir:

"Kulıbay, babasının birinci karısından, Tanabay ise daha küçük ikinci karısından doğmuştu. Ama Kırgız töresine, bir babadan olan çocuklar, bir anadan doğmuş gibi karındaş sayılırlar. Buna göre Tanabay öz kardeşine el kaldırmış, öz kardeşine kötülük etmiştir. $\mathrm{O}$ günlerde herkes bunu konuşmuş, dedikodusunu yapmıştı. Bugün geriye dönüp şöyle bir bakıyordu da, çok başka yargılara varıyordu. Tanabay ne yapmışsa kolhozun iyiliği için yapmıştı" (s. 47).

Tanabay kolhozun durumuyla ilgili sık sık Çora’yla görüşür. Her şeye rağmen bu dönem Tanabay için çok güzel bir dönemdir. "İhtiyar Turgay'ın dedikleri oldu. O yılın baharında yorganın yıldızı iyice parladı. Genci, yaşlısı herkes tanıdı onu. Bilmeyen kalmadı: "Gülsar!!" “Tanabay'ın yorgası!”, "Köyün övüncü, gururu... diyor, onu dillerinden düşürmüyorlardı" (s. 53).

Mayıs'ta Orta Asya Türk geleneklerinden Kökpar ve bunun gibi at üstünde oynanan yarışlar düzenlenmişti. Burada yazar-anlatıcı eskiyle bağın kopmaması adına geleneklerle bağ kurmuş ve bunu da geleneğin bir gereği olarak düzenlenen şenliklerle göstermiştir. Bir yandan at üstünde oynanan oyunlar bir yandan güreşler, ciritler oynanıyor bir yandan yarışmanın galibine âminler eşliğinde dualar ediliyor. Düzenlenen yarışlarda Gülsarı dört bir yana ün salmıştı ve Tanabay bu durumdan oldukça haz alıyordu. Şenlikten sonra Tanabay Gülsarı'yı alıp Bibican'ın evine gider ve geceyi orada geçirmeye karar verir. Ancak tabiat ana bu yasak ilişkiye son vermek ister gibi firtınalar koparır, göğ̈ inletir. Gülsarı bu durumdan oldukça rahatsız olur. Çünkü onun aklında yılkıdaki diğer kısraklar vardı. Gülsarı Tanabay'ın üzerinde beyaz fanilasıyla birlikte şimşek gibi yılkının yanına gider.

"Tanabay, çılgına dönmüş atın kendisini nereye götürdüğünü anlamıyordu bile. Yağmur yüzüne, gözüne, bütün gövdesine vuruyor, ama içi alev alev yanıyordu. Tek bir düşünce vardı kafasında: "Yılkı nerede? Aman Tanrım! Vadiye inip demiryoluna doğru gitmesinler, demiryoluna düşmesinler! Mutlaka kaza olur! Allahım, sen koru onları! Ey Arbak (ervah, atalar ruhu) sız koruyun yılkıyı! Sakın ayağın sürçmesin Gülsarı! Sakın düşme! Beni yılkıya ulaştır!” diyordu (s. 72-73).

Tanabay yılkıya döndüğünde eşi Caydar'ın ve komşularının yılkıyı sapasağlam bulup yerine almış olduklarını gördü. Eşi Caydar'ın ona sorumluluklarını hatırlatmasıyla yaptığından pişmanlık duyan Tanabay Gülsarı'yla tanıştığından bu yana ilk kez ağlamıştır. Caydar Tanabay'ı şu sözleriyle uyarmıştır:

"Giyinmeye de mi vakit bulamadın? Talihin yokmuş! Çizmenle pantolonunun ayağında olmasına şükür. Hiç utanmıyor musun? Artık genç de değilsin. Çocuklar boyuna yetişti! Sen ise..." (s. 74).

Bundan sonra yılkı toplanıp dağın yolunu tutmuştu. Göç kafilesi köyden iyice uzaklaştı. Gülsarı günden güne daha da gelişiyordu. İyi de bir aygır oluyordu zamanla. Bu arada kolhozda birtakım değişiklikler olur. Çora hastalanır, bu yüzden kolhoz başkanlığ görevini başkasına devretmişti. Her şey yavaş yavaş kötüye gitmeye başlıyordu. Gülsarı'nın ününün yayılması çok da iyi olmamıştı. Çünkü çok geçmeden at çiftliği başkanı İbrahim bir sabah elinde yeni kolhoz başkanının imzasını taşıyan bir kâğıtla gelir. Bu kâğıtta yazılanlar aynen şöyledir:

"Buyruk. 
Mustafa KARABULUT - Esma BULUT - Cengiz. Aytmatov's Novel "Elveda Gülsar" in

Terms ff Novel Technique

\section{Y1kıı Bakasov’a}

Gülsarı yorga, binek atı olarak kullanılmak üzere at korasına gönderilsin” (s. 82).

Tanabay bu yazıyı okuyunca dünyası başına yıkılmıştı:

“Ah Gülsarı! Onu vermeye dayanamazdı. Ne etse de vermeseydi Gülsarı'yı? Çok iyi düşünmeli, kendi durumunu da dikkate almalı, emre karşı gelmiş olmamalıdı" (s. 83).

Tanabay bugüne kadar her şeyi kolhoz için yapmıştı. Bu yüzden ne kadar acı ve zor da olsa yine kolhoz için Gülsarı'yı verecekti ki verdi de.

Bundan sonra Caydar'ın "kopuz" çalışması gelir. Kopuz, geleneğin, geçmişin sesidir, geçmişte Kırgız Türklerinin yaşadığı acıların sesidir. Gülsarı gittiği yeri ve sahibini hiç sevmemiştir. Bu yüzden defalarca geri gelir. Gülsarı'yı durduramayan kolhoz başkanı ve at çiftliği başkanı İbrahim, Gülsarı'nın ayağına zincir köstekler geçirir. Gülsarı'nın ayağına zincir kösteğin geçirildiği gün Tanabay kötü bir rüya görür. Rüyasında kan görmüştür. Rüyada kan görmeyi de kötü bir şeyin olacağına yoruyordu. Bu rüyadan Tanabay’ı eşi Caydar uyandırır. Caydar kendisine hayvanların dövüştügünü, gürültünün geldiğini söyleyerek Tanabay’ı hayvanların yanına gönderir. Tanabay karşısında Gülsarı'yı görünce şaşırır. Ama birdenbire Gülsarı'nın ayaklarında zincir kösteği görünce sinirinden çılgına döner. Bunun üzerine hemen bütün aile bireyleri Gülsarı'nın ayağındaki zincir kösteği çıkarırlar. Tanabay bu duruma çok üzülür.

"Tanrım! Ne kötülük etmişler sana! Kim vurdu bu zincirleri ayaklarına? Buna rağmen o kadar uzaklardan tâ buraya geldin ha! Ah zavallı sersem ah!” (s. 93).

Gülsarı bu olaydan sonra kolhoza teslim edilir. Ancak Gülsarı'nın tekrar kolhozdan kaçıp gelmesi üzerine zavallı hayvan iğdiş edilerek özgürlüğü elinden alınır. Daha sonra da koraya hapsedilir. Gülsarı'nın iğdiş edilmesi, Kırgız soyunun tehlikede olduğunu ifade eder bir bakıma. Romanın bu bölümünde neredeyse geçmişini yok etmeye çalışacak kadar unutan bir toplumun eleştirisi niteliğinde bölümlerle karşılaşmaktayız: "Elveda Gülsarı romanı denilebilir ki bütünüyle gelenek ile yenilik arasındaki bu uzlaşmazlığı anlatır. Fakat bu roman geleneğin aşama aşama yok edilmesinden çok kendi geleneğine şuursuzca kıyan bir neslin özeleştirisi niteliğindedir” (s. 173). Gerçekten de Tanabay'ın kişiliğinde bir toplumun değerlerine, geçmişine sahip çıkmaması söz konusudur. Nitekim romandaki şu bölüm mevcut durumu izah etmesi açısından önemlidir:

"Oysa gençliğinde kendisi de eski törelerin mezarını kazanlardan biri olmuştu. Hatta bir komsomol toplantısında keçe çadırlardan, çadır evlerden söz etmişti. Keçe evlerin yok edilmesini istemişti. Çadır evler devrim öncesinin evleridir ve bunlardan vazgeçilmelidir, demişti” (s. 95).

Tanabay bunları söyleyerek geleneğinden uzaklaşmış biri olarak çıkar karşımıza. Ancak Tanabay bu söylediklerinden pişman olacaktı. Romanda da ifade edildiği gibi hayvancılıkla geçinenler, dağlarda sürü otlatanlar, kışlatanlar çadırsız yapamazlardı. Tanabay pişmanlığını şu sözlerle ifade eder: 
"Tanabay o sözleri nasıl söylediğine bugün hayret ediyordu. Pişmanlık içindeydi. Keçe çadır, kendi milletinin, atalarının en güzel buluşlarından biriydi. İnsanoğlu bugüne kadar bu durum için, göçüp konanlar için, daha iyisini bulamıştı. Yüzyıllar boyu geliştirilmiş, her şeyi değerlendirilmiş, sınanmıştı. Bunu nasıl anlayamamış, çadırların yıkılmasını istemek gibi bir sözü ağzına nasıl almış, nasıl dili varıp söylemişti!"' (s. 96).

Tanabay bu pişmanlığını dile getirdikten sonra kendilerinin olan çadırlarına artık yamaların da yetmediğini görünce köye yeni bir çadır almaya gider ama artık eski çadır ustaları yoktur. Bunun üzerine kolhoza gider. Kolhoz kendilerine çadır ev yerine palatka denilen bez çadır vermek isteyince Tanabay'ın karısı Caydar buna "palatkada oturacağıma elek gibi delik deşik keçe çadırda otururum daha iyi" diyerek karşı çıkar. Tanabay ve ailesi, ne kadar kötü durumda olursa olsun kendi çadırlarında mutluydular. Çadır belki de kendi geçmişlerinin bir parçası olması hasebiyle onlara mutluluk vermektedir. Unutulan değerlerle ilgili bir başka eleştiri de şu cümlelerde görülmektedir:

"O paslı zincire evirip çevirip baktı ve ustalığına hayran kaldı. Bunu yapan kişi gerçekten de büyük bir usta idi. Eski Kırgız ustalarının hünerlerinin, akıllılıklarının bir belgesiydi. Bugün böylesini kimse yapamazdı. Artık zincir kösteklere gerek kalmadığ 1 için bu işçilik unutulup gitmişti. Yalnız o muydu unutulup giden. Çok üzüldü. Gümüşten, bakırdan, demirden, ne güzel aletler, ne güzel süslemeler, tahtadan ne güzel oymalar, ne güzel deri işleri vardı. Bütün bunlar yok olup gitmişti. Şimdi her şeyi alüminyumdan yapıyorlar: Tencereyi, tabağı, kaşığı, sürahiyi, leğeni, her şeyi. Nereye gitsen hep aynı şeyleri görüyorsun. Hem ne kaba şeyler! Yazık! O ünlü eyer ustaları yok artık. Ne eyerler yapılırdı eskiden! Her eyerin bir tarihçesi, künyesi vardı. Kim yapmış, kime yapmış, ne zaman yapmış, yapan kişi karşılık olarak ne almış? Hepsi bilinirdi” (s. 94-95).

\section{Bölüm}

Geriye dönüşlerin çokça yaşandığı romanın bu bölümünde Tanabay ve Gülsarı yine o yokuş yoldadır: "Geceydi sır dolu bir gece. Yaşlı bir adam ve yaşlı bir at." (s. 105). Bu bölümdeki vaka halkaları:

V1: Kolhoz sisteminin emekleri ve duyguları sömüren bir sistem oluşunun Tanabay tarafindan fark edilmesi.

V2: Kolhozda işlerin yolunda gitmemesi dolayısıyla Tanabay'ın arkadaşı Çora'nın isteği üzerine koyun çobanlığı yapmaya karar vermesi.

V3: Tanabay’ın kolhozun düzenlediği toplantıya katılması ve yapamayacağ 1 sözler vermesi.

V4: Yılkıcılığın önemini yitirmesi.

V5: Kolhozun kuruluş yılları ve o yıllarda yaşanan olaylar.

V6: İlçe merkezinden kolhozu denetlemek için gelen müfettiş Segizbayev'in koyunların ölümünden/telef olmasından Tanabay'ı suçlaması ve Tanabay'ın da müfettişe saldırması.

V7: Parti ilçe komitesinin olağanüstü toplanıp Tanabay’ı parti üyeliğinden ihraç etmeleri. 
V8: Çora'nın vefatı ve Tanabay'a vasiyeti.

V9: Tanabay'ın parti üyeliğine davet edilişi ve Tanabay'ın bu teklifi reddedişi.

V10: Gülsarı'nın ölümü

Elveda Gülsarı, savaş sonrasını konu edinen bir romandır. Savaş biteli onlarca yıl olmuştur. Ancak kolhozda işler hiç de yolunda gitmez. Hatta her şey savaştaki durumdan daha kötü bir haldedir. Tanabay'ın kafası sürekli bu düşüncelerle doludur:

"Gerçekten de başlangıçta işler biraz düzelmişti. O uğursuz savaş olmasaydı belki daha düzelecekti. Peki, ama savaş biteli onlarca yıl oldu da durumlar niçin düzelmiyordu? Onlar, eskimiş çadırlarının üstüne nasıl yama üstüne yama vuruyorlarsa kolhozun işleri de öyle gidiyordu: Yama üstüne yama vuruyor, hiçbir gediği kapatamıyorlardı. Birini tıkamaya vakit kalmadan bir başka gediğin açıldığını görüyorlard1. Neden böyle oluyordu" (s. 110).

Tanabay artık kolhozun insanların duygularını, emeklerini sömüren bir sistem olduğunu, kendilerinin de bu acımasız çarkın bir dışlısı olduğunu idrak etmeye başlamıştır. "Nitekim roman sonlarına doğru Tanabay gerçekleri kendi gözüyle görür, Parti yöneticilerinin ikiyüzlülüğünü veya onların temsil ettiği rejimin kendilerine ne kadar yabancı olduğunu, rejim yüzünden nelerin yok edildiğini fark eder" (Söylemez, 2010: 27). Gençlerin şehir hayatına özenip kolhozdaki işlerle uğraşmak istememesi üzerine Tanabay'ın en iyi arkadaşı Çora kendisine bundan sonra at değil çoban bakıcılığı yapmasını söyler. Tanabay başlangıçta biraz direttiyse de Çora onu ikna etmiştir. Ancak Tanabay için koyun bakıcıllığ hiç de kolay olmayacaktır. Çünkü “Tanabay'ın koyun çobanlığına başladığı zamanlar kış ayına denk gelir" Tanabay'a beş yüz kadar koyun verilir ve bu dönem koyunların yavrulama zamanıdır. Ayrıca koyunların doğurması için bir yer bile yapılmamıştır. Ama Tanabay koyunlar için bir yerin dahi yapılmadığından haberi yoktur. Bir gün toplantı merkezine doğru bir kamyonla yola koyulurlar. Toplantı merkezine vardıklarında Tanabay, Gülsarı'nın da orada olduğunu görür. Çora toplantıya sarı tayla gelmişti. Tanabay sarı tayı görünce hem şaşırır hem de mutlu olur. Çora toplantıya katılmadan önce Tanabay'a toplantı salonunda söylemesi gerekenleri bir bir söyler:

“-Neden söz edeceğim? Konu ne?

-Ben bir komünistim, dersin, bir komünist olarak geri kalmış koyunculuk işinde çalışmaya karar verdiğini söylersin.

-Hepsi o kadar mı?

-O kadar olur mu hiç. Bu görevi isteyerek üstlendiğini söyleyecek ve söz vereceksin. Her yüz koyundan yüz on kuzu elde edeceğine, her koyundan üç kilo yün çıkaracağına partinin ve halkın huzurunda söz vereceksin." (s. 120).

İşte, Tanabay tam da bu sözleri söylemişti, ne eksik ne fazla. Tanabay yapamayacağı işler için söz vermiş ve koyun bakıcıllğı işine başlamıştı. Tanabay toplantıdan sonra ışının başına döner. Ancak koranın halını görünce dehşete düşer. Çünkü savaş sonrası her şey gibi kuzulama/yavrulama korası da yıkık-dökük bir harabeydi. Bunun üzerine "Tanabay, karısı ve bir yardımcı kadınla çok güç şartlarda çalışarak bir haftada korayı düzeltirler. Erken doğumlar ve ağır kış şartları nedeniyle 
koyun ve kuzuların ölmesi üzerine kolhoza gelen müfettiş, Tanabay'1 kolhoz malına isteyerek zarar veren bir halk düşmanı olmakla suçlar" (Kaplan, 2009: 305). Tanabay her ne kadar korayı düzeltmek için uğraşırsa da bu mümkün olmaz. Giriştiği bu koyun bakıcılığ 1 işinin üstesinden gelmesi de çok zordur. "Koyunlara bakmak atlara bakmaktan elbette daha kolaydı, ama Tanabay çobanlığa alışamamıştı daha. Ona göre atların yerini hiçbir şey tutamazdı. Varsın yılkıcılığın eski önemini yitirdiğini söylesinlerdi. Motorlu araç çıkınca, yılkının nalı dama atılmış görünüyordu. Koyun üretme işi daha kazançlıydı: Yün, et, süt, deri alınıyordu koyunlardan" diye düşünüyordu. Tanabay. Tanabay'a koyun bakıcılığ 1 işinde yardımcı olacak bir kişi bile gönderilmemişti. Bu yüzden eşi Caydar ve yardımcı bir kadın kendisine yardım ediyordu. Tanabay her ne kadar bu iş için koyun üretme birimlerinden sorumlu İbrahim'e başvurmuşsa da hiçbir sonuç alamamıştır. Tanabay söz verirken bunları düşünmemişti. Bunun üzerine koyun çobanllğının üstesinden gelemeyeceğini düşünür ve bir yandan Çora'yı suçlar, bir yandan da elinden bir şey gelmediği için kendisine kızar.

"Suç kendisinindi. Ne yaptıysa kendisine yapmıştı. Düşünmeden konuşmuştu. Onların söyle dediklerini söylemiş, onların istediklerini yapmıştı. Ama onların umurunda mı? Söz veren onlar olmadığına göre kolayca kurtarırlardı kendilerini. Yalnız, Çora için üzülüyordu Tanabay. Çünkü o da iyi durumda değildi. Bir gün iyi olsa iki gün hasta oluyordu. Ömrünü başkalarına dert anlatmakla, onları inandırmaya çalışmakla geçirmişti. Ama neye yaramıştı bütün bunlar?” (s. 132).

Tanabay tüm bu olanların hesabını kolhozun yeni başkanı Aldanoviç'e, İbrahim'e ve Çora'ya sormak için atına binecekken Caydar kendisini durdurur. Tanabay bir süre sonra sakinleşir ve ağabeyi Kulıbay'la yollarının ayrıldığı, Çora'yla tanıştığı yılları hatırlar. Tanabay ve ağabeyi Kulıbay daha çocukken uzaktan akrabaları olan bir zenginin koyunlarını güdüyorlardı. Bir yıl sonra kandırıldıklarını anlamış ve oradan ayrılmışlardı. Daha sonra Kulıbay başka bir ağanın yanında çobanlık yapar, Tanabay ise Aleksandrovka'da adil bir Rus çiftçi olan Efremov'un yanında ırgat olarak çalışır. Devrimin gerçekleşmesiyle her şey alt üst olur ve tam da bu zamanlarda Tanabay Irgatlar ve Yoksul Köylüler Komitesi'ne üye seçilir.

"Çora ile işte o zamanlar karşılaşıp tanıştılar. Çora okumuş, kültürlü bir adamdı... Sonra bir komsomol ${ }^{3}$ hücresine katıldı. Burada da Çora ile beraber çalıştılar. Partiye de birlikte girdiler. Yoksullar yükseliyor, işler hızla ilerliyordu. Kolektifleşme başladığı zaman Tanabay kollarını sıvadı, canla başla çalıştı. Köylülerin yeni hayata geçişleri için bu uğurda toprak, hayvan, emek ve büyük ideal... Her şeye ortak olmak için Tanabay çalışmayacaktı da kim çalışacaktı? Gözleri çıksındı kulakların (toprak sahiplerinin). Yok olsunlardı!” (s. 153-154).

Tanabay bu büyük hedefi gerçekleştirmek adına öz kardeşini dahi kulak listesine aldı ve bunun gereği olarak da Kulıbay'ı -ağabeyini- Sibirya'ya sürdürmüştür. Kulıbay'a yapılan bir haksızlıktır bu. Çünkü Kulıbay kazandığı her şeyi alnının teriyle elde etmişti. Kulıbay:

“-Benim zengin bir ağa olduğumu, kulak olduğumu nasıl söylersin? Neyim varsa kendi emeğimle, gece-gündüz çalışarak alın terimle elde ettim. Bunları çok

\footnotetext{
${ }^{3}$ Komsomol: Eski Sovyetler Birliği’nde Komünist Partisi'nin gençlik yapılanması.
} 
görüyorsan hepsini alın. Ama beni kulak grubuna, ağa grubuna sokmanız neden? Sen hiç Allah’tan korkmaz mısın Tanabay?" (s. 155) diyerek ona hesap sorar ama Tanabay bu düşüncesinde kararlıdır.

$\mathrm{Bu}$ geriye dönüşten sonra zar zor yanına yardımcı diye aldığı Bektay da kendisini harabelik korada, üstelik bir sürü koyunla daha yüzüstü bırakıp gider. Gelen müfettiş Segizbayev:

“-Rezalet bu! Nereye gitsem aynı şey. Şunlara bak!

-Çora'ya bakarak söylüyordu. Sonra Tanabay'a döndü:

-Ne oluyor yoldaş? Dedi ölü koyun yığınlarını göstererek. Sen komünist bir çoban olduğun halde kuzuların neden ölüyor?” (s.169) diyerek Tanabay’ı koyunları bilerek öldürüyormuş gibi gösterir. Bunun üzerine Tanabay küplere biner ve tırmıkla müfettişe saldırır. Tanabay'ın en çok öfkelenmesine sebep olan hususlar müfettişin bunca yıl kolhoz için canını dişine takan hatta bu uğurda babasını, ağabeyini gözden çıkaran, ortada kora adına verilen sözlerden her birinin yerine getirilmeyişine ve yine de pes etmeden çalışmasına rağmen kendisini "kolhoz malına isteyerek zarar veren bir halk düşmanı" denilmesidir. Tanabay buna dayanamaz, çünkü sadece kolhoz istediği için Gülsarı'sından bile feragat etmiş̧tir. Bundan sonra Segizbayev'ın şikâyeti üzerine parti ilçe komitesi toplanır ve Tanabay'ın parti üyeliğinden çıkarılmasına karar verilir.

"Ey Tanrım! Hayatımın aslı haline gelen çalışmam, ömür boyu çabalamam, emeklerim, baş dayanağım olan armanım (ülküm) ne oldu? Nereye gitti? Ölesiye bitesiye çalışmamın sonunda, ola ola halk düşmanı mı olacaktım? Bana böyle mi diyeceklerdi? Bir gün bana böyle diyeceklerine asla inanmazdım! Ben zavallı yıkıkdökük kora için, sürgüne tutulan, kırılıp giden kuzular için, talihsiz Bektay için dertlenip duruyorum. Bütün bunlar kimin umurunda? diye düşünüyordu Tanabay" (s. 176-177).

Tanabay bu vakadan sonra ağlar ve kimseyle konuşmadan hızlıca evin yolunu tutar. Çora onunla konuşmak için hızlıca peşinden gider ve Aleksandrovka yokuşunda Tanabay'a yetişir. Ancak Tanabay onu dinlemez. Tanabay'ın bu sözleri zaten hasta olan Çora'nın kalbine bıçak gibi saplanmıştır. Çora kalbi da çok ağrımaya başlayınca derhal eve gider. Çora ölümün pençesine takıldığını, bu defa kurtulamayacağını bilir ve bu yüzden eve varır varmaz ilaçlarını alır. İlaçlarını aldıktan hemen sonra bütün köye evinde toplanması için haber gönderir. Tabi biricik dostu Tanabay’a da haber gönderilir. Köydeki herkes, komünistlerin tümü gelince Çora her şeyi anlatacaktır:

"Her şeyi, her şeyi anlatmam gerek onlara. Bu 1şıı nasıl olduğunu, Tanabay'ı partiden nasıl ihraç ettiklerini anlatacağım. Her şeyi anlatacağım. Herkes her şeyi bilsin: Tanabay'ın partiden çıkarılmasına karşı geldiğimi bilsinler. Aldanov hakkında ne düşündüğümü de bilsinler. Benden sonra onun ne söyleyeceğini de, ne yapacağını da görsünler. Komünistler kendileri karar versin. Kendimi de olduğum gibi anlatacağım. Kolhozumuz hakkında, insanlarımız hakkında her şeyi anlatacağım. Yeter ki bunları anlatacak kadar zamanım olsun” (s. 189).

Çora bu konuşmaları yaparken Aytbay adında bir çoban da Tanabay'a Çora'nın çok hasta olduğunu bildirir. Ama Tanabay, Çora'nın her zamanki gibi hasta 
olduğunu ve tekrar kalkacağını söyleyerek Aytbay’1 gönderir. Aytbay “İyi düşün, bu defa çok ağır hasta. Okuldaki oğlunu da çağırmışlar, istasyona karşılamaya gitmişler" der ve gider. Tanabay her ne kadar gitmek istemese de karısı Caydar tarafından ikna edilir. Caydar: "Bak Tanabay, bugüne kadar senden benim için bir şey yapmanı hiç istemedim. Şimdi istiyorum. Acını, gücenmişliğini bana bırak. Git oraya! İnsanlığını unutma" (s. 194) der ve Tanabay karısından gelen bu emre itaat ederek yola çıkar. Daha sonra Çora ölür. "Biricik dostu Çora dönüşü olmayan yolculuğuna çıkarken, son sözünü söylemek, helalleşmek için onu çağırmış, oysa kendisi inatla bu çağrıyı reddetmişti” (s. 197). Tanabay köye vardığında Kazakların da oraya geldiğini, ağıtlar yakıldığını görmüştür. Tanabay oraya gittiğinde Çora'nın oğlu Samansur'u görür ve birlikte ağlaşırlar. Tanabay'ın şimdiki ağlayışı ömür boyu yitirdiği her şey içindir. Artık hiç göremeyeceği Çora için, işlediği suçlar için, karşısında duran Bibican için, kader ikisini ayırdığı için, o müthiş firtınalı gece için, Bibican'ın yarsız ve yalnız kalması bir mutlu ve aydınlı gün görmeden yaşlanıp gitmesi içindir. Karalara bürünmüş Gülsarı için, çektiği bunca sıkıntı için ve eziyetler için, dile getiremeyip içine attığı her şey için ağlar (s. 199).

Cenaze alayından sonra Samansur, Tanabay'a vasiyeti açıklar: "Oğlum, benim Tanabay'ıma söyle, ondan özür diliyorum, beni bağışlamasını, bana kızmamasını istiyorum. Partinin ilçe komitesine, benim parti üyelik kartımı o götürüp teslim etsin" (s. 202) demiştir Çora. Tanabay bu vasiyeti yerine getirmek için gittiğinde Kaşkatayev sekreterine çok meşgul olduğunu, onu görmek istemediğini söyler. Tanabay açıktan açığa dışlanmış hatta ötekileştirilmiştir. Tanabay evine, geçmişini simgeleyen- çadırına gider ve zamanları aşan o kopuzun tellerinden çıkan acı ezgilerle ağlar. Burada Kırgız ağıtını dinler Tanabay. Tıpkı ağıttaki yaşlı adam gibi o da yalnızdır, acı çekmektedir.

Tanabay için acıların, sıkıntıların sonu yok gibidir. Çünkü şimdi de sevgili tayı "yorga Gülsarı"sı Aleksandrovka yokuşunda can çekişmektedir. Çora'dan sonra sıra Gülsarı'ya gelmişti. Tanabay bütün bir gece Aleksandrovka yokuşunda yorga atı Gülsarı'nın başında beklemiş, bütün bir gece geçmişini düşünmüş ve sonunda taypalma yorga Gülsarı'sını son yolculuğuna uğurlamıştı. Roman Tanabay'ın gökyüzünde uçan yabankazlarına bakıp derin bir iç çekmesi ve "Elveda Gülsarı! Elveda!" demesiyle son bulur.

\section{Konu ve Tematik Düzlem}

Kırgız yazar Cengiz Aytmatov eserlerinde evrensel yönelişlerle aşk, dostluk ve savaş gibi konuları işler. Özellikle insanlığ 1 derinden etkileyen savaşa geniş yer verir. II. Dünya Savaşı gibi büyük bir savaşın tanığı olarak kaleme aldığı eserleriyle dünyaca ünlü bir yazar olmayı başarır (Aylanç, 2010: 50). Elveda Gülsarı'da aşk, dostluk, savaş gibi konular yer alır. Ancak savaş daha çok bitmiş haliyle yer alır eserde. Nitekim eserin kendisi de bir savaş sonrası romanıdır. Savaşın tanığı bir yazarın savaşta ve sonrasında yaşananları eserlerine yansıtması bu bakımdan doğaldır. Elveda Gülsarı romanında Gülsarı adlı sarı tayın roman başkişisi gibi görünmesi, konunun bir atın hikâyesi olduğu anlamına gelmez. Okuyucu romanı ilk okuduğunda sıklıkla Tanabay ve Gülsarı'nın hayat hikâyesinin, ikisi arasındaki bölünemez sevginin anlatıldığını görüp bu eserin dostluk üzerine yazılmış bir roman olarak da görebilir. Ancak her ne kadar roman Tanabay ve Gülsarı'nın etrafında şekilleniyor gibi görünse de asıl konu Tanabay ve onun gibi devrime inanmış ve bu 
uğurda ağır bedeller ödemiş Kırgız Türklerinin acı dolu hikâyesidir. Eserde II. Dünya Savaşı'nın henüz bittiği zamanlarda, toplumun gerek sosyal gerek ekonomik ve gerek psikolojik durumları etraflıca işlenmiştir. Savaşın kendisi bir yıkımdır. Savaş sonrası ise bu yıkımdan arta kalan açlık, sefalet, zulüm herkeste tek tipleşen duygular ve bir tür toparlanamayıştır. Eserde savaş sonrası yeniden toparlanma adı altında kolhoz sistemi yerleştirilmeye çalışılmaktadır. Başlangıçta amacından sapmayan bu sistem daha sonra bir tür sömürü sistemi halını alacaktır. Bununla mücadele etmek sadece cesaret istemiyor; hiç yoktan bedel ödemek gerekiyor. Roman Sovyet rejimine bir eleştiri niteliği taşır. Eserde; İnsanı, insanlığı, emeği önemsemeyen bir rejim eleştirisi vardır. Burada hedeflenen sorgulamayan, mankurtlaşmış ve itaatkâr insanlar oluşturmaktır. Romanda işlenen önemli bir konu da soyun, geçmişin unutturulmasıdır. Bunların yanında yukarıda ifade edildiği gibi eserde yan konu olarak aşk, dostluk, fedakârlık gibi konular da işlenmiştir.

\section{Kișiler/ Şahıs Kadrosu}

Anlatmaya dayalı türlerde tematik düzlem, olay veya durumlar kişiler üzerinde gerçekleşir. "İtibari eserde nakledilen veya değişik şekillerde ifade edilen vakanın zuhûru için gerekli insan ve insan hüviyeti verilmiş diğer varlıklar ve kavramlar 'şahıs kadrosu' olarak adlandırılır. Vakaya iştirak eden insan dışındaki varlık ve kavramlar metinde yüklendikleri fonksiyon bakımından şahıs karakteriyle karşımıza çıkarlar" (Aktaş, 2005: 132). Bu durumda Elveda Gülsarı romanındaki geleneksel roman anlayışında yer alan kişilerdir. Bu konuda Yaşar'ın tespitleri önem arz etmektedir: "19. yüzyıl Fransız romanlarında özellikle Balzac'ta geleneksel kişi ve hikâye kavramları toplumun belli bir görüşüne ve insanın kaderine bağlanmıştır. Bu iki unsur roman kahramanına ve anlatı tekniğine belli bir şekil vermiştir. Örneğin geleneksel romandaki kahramanın bir ismi, cismi, unvanı önemli bir fonksiyonu vardır. Bunlara, Balzac'ın romanlarındaki kahramanların önemli derecede mal varlığına sahip olmaları da eklenebilir." (Yaşar, 2008: 3). Dolayısıyla kahraman, toplumun belli bir kesimini temsil eden bir öge durumundadır.

Romanda ön plana çıkan kişiler: Tanabay, Gülsarı, Çora, Caydar, Kerımbekov, Samansur, Kulıbay, Bıbıcan, İbrahim, Bektay, Segizbayev, Kaşkatayev, Aldanov, Aytbay, Turgay ve Tanabay'ın oğlu ve gelini.

\subsection{Birinci Dereceden Kahramanlar}

İnsan ve insanla ilgili her şey edebiyatın temel konularından biri olmuştur. Metinlerde geçen olaylar da şahıs kadrosunda yer alan insan, insan dışındaki varlık ve kavramların etrafında gelişerek olay örgüsünü tamamlayıcı unsurlar haline gelmiştir.

Tanabay Bakasov: Bu romanın başkişisidir. Romanda geçen her vaka ve vaka parçası Tanabay Bakasov'un etrafında gelișir. Tanabay toprak sahiplerini ortadan kaldırmak için kolhoz denilen kolektif işbirliğine dayanan sistemin ülkede yerleşmesi için canla başla çalışmış birisidir. Hatta bunun için öz kardeşi Kulıbay'ı bile haksız yere Sibirya'ya sürdürmüştür. Tanabay romanın başında, savaştan dönmüş ve gençken çalıştığ demircilik işinde çalışıyorken yer alır. Aytmatov'un babası da tıpkı Tanabay gibi komünist rejimin mükemmel suretle işlemesi için elinden geleni yapmış ama sonunda hayal kırıklığına uğramış, rejim tarafından dışlanmış ve ezilmiştir. Deyim yerindeyse güvendiği dağlara kar yağmıştır. Tanabay 
romanda mücadeleci bir şekilde hareket eder. Ancak bu mücadeleci yapısının yanında pasif bir kişiliğe sahiptir. Parti üyeliğinden ihraç edilirken kendisini savunmaz aksine suçlu olduğunu düşünür ve bu duruma ses çıkarmaz. "Aytmatov insan psikolojisinin daha karmaşık dünyasında, Tanabay karakterinde insanoğlunun masumluğu ve suçluluğunun çözülemez çapraşıklıklarını tasvir eder" (Söylemez, 2010: 27).

Elveda Gülsarı'nın başkişisi Tanabay, "rüzgar ekip firtına biçen” trajik bir tiptir. Gençliğinde büyük bir cesaretle savunduğu, uğruna en yakınlarını bile feda etmekten çekinmediği sistemin, kendi çocuklarını yiyen bir deve dönüştügünü üzüntüyle seyreder (Korkmaz, 2004: 100). Bu durum başka romanlarda da işlenmiştir. Tanabay'ın düştüğü vaziyet Halit Ziya'nın Nesl-i Ahir romanında başkarakter Süleyman Nüzhet'in sözlerini çağrıştırmaktadır. Hüseyin Yaşar bu duruma şu ifadelerle işaret etmektedir: "Süleyman Nüzhet, inşa sürecinde, öz eleştiri yaparak hata yapmaktan endişe duyar ve süreci az hata ile tamamlamaya çalışır. Bu bağlamda inşa çalışmaları sonucu ileride yaşanacak yönetim değişikliğinin yaratacağ1 olumsuzlukları edebi söyleme katar... Yaşanacak devrimin yaratacağ 1 muhtemel meselelerden endişe duyar. Kahramanın bu kaygisı, Anatole France'ın (1844-1924) Tanrllar Susamışlardı (Les Dieux ont soif) (1912) adlı romanını çağrıştırır. France, anılan eserinde, Fransız devrimini yapan Cumhuriyetçilerin, Aristokratları, Federalistleri ve kral yanlılarını yargılayıp giyotine göndermek için kurdukları mahkemelerin, zamanla suçsuzları ve katıksız Cumhuriyetçileri bile idama mahkûm edip birbirlerini nasıl boğazladıklarını romanlaştırır. (Yaşar, 2013: 304-305).

Bununla beraber Tanabay romanda okumuş, bilgili, nerede ne söyleyeceğini, kiminle nasıl konuşulması gerektiğini bilen Çora'nın aksine eğitim görmemiş, aklına ilk geleni söyleyen, kiminle nasıl konuşulması gerektiğini bilmeyen, devrim gibi aceleye gelmeyen bir işin bile bir anda olmasını isteyecek kadar sabırsız birisidir. $\mathrm{Bu}$ özellikleri dışında Tanabay başkasının aklıyla hareket eden biridir. Bunu romanda Tanabay'ın en iyi dostu Çora ve karısı Caydar bilir. Tanabay iyi bir eş de değildir. Nitekim romanda evli olduğu hâlde başka bir kadınla yasak bir aşk yaşamıştır. Tanabay hayvanlara karşı çok merhametlidir. Öyle ki sevgili atı Gülsarı için defalarca ağlamıştır. Onu ilk aldığı zamanlar zayıf olan sarı tay, Tanabay'ın ellerinde hayat bulmuştur. Sarı tay üstün özellikleriyle ününü dört bir yandan duyurmuştur. Çünkü at doğuştan yorgaydı ve eşsiz bir at cinsindendi. Binicisini hiç sarsmayan su gibi akıp gidebilen bir attı Gülsarı. Sarı tay aynı zamanda Tanabay'ın dert yoldaşıdır.

Gülsarı: Gülsarı, romanda simgelediği değerler bakımından dikkatleri çeker. Tanabay için Gülsarı'nın yeri bambaşkadır. Öyle ki karısından daha çok atıyla vakit geçirir. "Gülsarı" ve "Tanabay" isimleri romanın pek çok yerinde birlikte anılır. Bu onların ayrılamaz oluşlarıyla ilgilidir. Ancak bu birliktelik, kurulan bu dostluk çok uzun sürmez. Çünkü Tanabay'ın canla başla çalıştı̆̆ komünist rejim onu kendisinden alır. Böylece kolhoz çalışanlarının önde gelen isimlerinden biri olan cesur Tanabay da rejime tabi kılınmıştır. Bu bir nevi Tanabay'ın çalışmasına karşılık ödediği acımasız bir bedel olmuştur. Rejim tarafından alıkonan Gülsarı, binicisi Tanabay'a gösterdiği uysallığı başkalarına göstermez -Çora haricinde- . Geniş bozkırda özgürce koşan Gülsarı, gittiği yerde durmayıp yılkıya kaçtığından rejim tarafından iğdiş edilir. Gülsarı'nın iğdiş edilmesi özgürlüğüne ve nesline, soyuna vurulan büyük bir darbedir. Yazar dışı tay Gülsarı'nın iğdiş edilişini Kırgız 
toplumunun soyunu devam ettirememe tehlikesi ve değerlerin yitirilmesi dolayısıyla ele alır.

"Gülsarı hayvancılığın ve mazinin sembolü olduğu kadar hürriyetin de sembolüdür. O kadar hürdür ki gem, yular ve eyere bile zor alışır. Dağlarda, bayırlarda koşmaya, serazat yaşamaya alışmıştır. Romanda ona eyer vurulması atın gözüyle önemli bir hâdise olarak tasvir ediliyor" (Ercilasun, 2013: 420).

Romanda birçok olayın "at"ın gözünden verildiği dikkatleri çeker. "Roman boyunca bir atın gözünden insanlar ve yaşam irdelenir. Gülsarı'nın sevinçleri, hüzünleri, acıları, korkuları derinlemesine işlenir. Bu noktada Aytmatov'un yazınsal tavrı Gülsarı'yı insanlaştırmak ya da ona insanı değerler yüklemek değil, atı at olarak ele almaktan yanadır... Yazarın Gülsarı'nın istek ve duygularının insanlarca hiçe sayılmasına veya insanların Gülsarı'ya yaptıklarını Gülsarı'nın bir türlü anlamlandıramamasına duyduğu tepki, romanın birçok bölümünde fark edilir" (Alparslan, 2014: 14). Atın iğdiş edilmesi, hayvancılığın önemini yitirmesi gibi tabiat sorunlarının ve insanların emek harcadığı işlerden karşılık görememeleri gibi sorunların sorumlusu Elveda Gülsarı'da "insan” olarak gösterilir. Gülsarı'nın önemli bir özelliği de sahibini doğacak kötü durumlara karşı uyarması, haberdar etmesidir. "Her canlıda olan içgüdüsel tepki elbette atta da var. Gülsarı yaklaşan felaketleri de sahibine önceden haber verir. Fırtınalı bir geceye karşı sahibini uyarır" (Akça, 2017: 119).

\subsection{Norm Karakterler}

Norm karakterler romanın asıl kahramanını yer yer yönlendiren, olayların gidişatını olay örgüsü içindeki hal ve tavırlarıyla veya sözleriyle etkileyen karakterlerdir. "Norm karakterler başkişinin olgunlaşmasına ve bilinçlenmesine yardım eden karakterlerdir. Bu kişiler başkişiyi olumlu yönde etkiler" (Karabulut, Güvenç, 2018: 118).

Çora: Çora Tanabay üzerinde önemli bir etkiye sahip olmuştur. Tanabay'ın Gülsarı'yla tanışmasına vesile olan da bir nevi Çora'dır. Çünkü Çora daha önce demircilik işinde çalışan Tanabay’ı yılkıcı olmaya razı etmiş ve bu sayede de Turgay'un kendisine verdiği yılkının içinde Gülsarı'yı tanımıştır. "Çora ile o, eskiden beri iki can dost idiler. Eskiden, tâ komsomol oldukları günlerde, bir kolhoz kurmaya, zenginlerin, kulakların (toprak sahiplerinin) mal ve mülklerini bu kolhoza katmaya birlikte karar vermişlerdi" (s.21). Çora daha sonra Tanabay'1 koyun çobanlığ 1 işine de ikna etmiştir. Çora karakter itibariyle çalışkan, dürüst, idealleri olan, bilgili, görgülü, yumuşak huylu ve herkese iyi davranan birisidir. Tanabay en çok da Çora'nın yumuşak başlı olmasına kızmış, ona hep sitem etmişti. Çora da ona şunları söylemişti:

"Ah Tanabay! Tanabay! Hayat sana hiçbir şey öğretmemiş, pek saf kalmışsın. Gençliğinde nasılsan şimdi de öylesin. Bütün meseleleri kestirmeden bir çırpıda halletmek istiyorsun! Oysa zaman çok değişti. Artık nerede ne söyleyeceğini, kimlerin önünde nasıl konuşacağını bilmen gerek. O zaman her şey iyi gider, başın derde girmez. Başkaları nasıl konuşursa sen de öyle konuşacaksın. Yumuşak, okşayıcı konuşacaksın. O zaman her şey yerine oturur, düzelir. Seni kendi haline bıraksam, ters bir şeyler söyler, her şeyi berbat edersin. Sonra da bunun cevabını, bunun hesabını vermek bize düşerdi (s. 124-125). 
Caydar: Olay örgüsünün gidişatı üzerinde etkili bir diğer 1sım Tanabay Bakasov'un karısı Caydar'dır. Caydar romanda hem iyi bir anne hem iyi bir eş, hem çalışkan, fedakâr bir çalışan, hem de Tanabay'ın işlerini düzenleyen bir karakterdir. İyi bir anne oluşunu şu cümlelerden anlamaktayız:

"Bir defa Caydar yatılı okulda okuyan çocuklarını görmek için gitti, ama hiç gecikmeden dönüp geldi”, Ertesi gün anaları dönüp gelince nasıl sevindiler, nasıl!","Caydar yokken ocaktaki ateş bile alevsiz, korsuz, bir yetim gibi kalıyordu". $\mathrm{Bu}$ ifadelerden anlaş1lyyor ki Caydar bulunduğu ortama sevinç, mutluluk getiriyor. Çalışkan, fedakâr ve iyi bir eş olduğu ise Tanabay'ın harabeye dönmüş at korasında gösterdiği çabalarından anlaşılıyor. Tanabay ise bu cefakâr, eşine sadık kadını, yani karısını aldatır. "Aytmatov'un eserleri dikkatle incelendiğinde 'yasak aşkın' onun eserlerinin yapısında önemli bir yer tuttuğu görülecektir. $\mathrm{Bu}$ durumun yazarın hatıralarıyla yakından ilgisi vardır. Aytmatov evli ve iki çocuk babasıyken Bübüsara isminde bir balerinle büyük bir aşk yaşamıştır" (Akça, 2017: 27). Caydar kendisini aldatan kocasını "Hiç utanmıyor musun? Artık genç de değilsin. Çocuklar boyuna yetişti! Sen ise..." (s. 74) sözleriyle uyarır ve Tanabay da bu yaptığından pişmanlık duyarak eşinin yanına döner. Caydar yerine göre Tanabay'ın işlerinin yolumda gitmesi için bir yönlendirici de olur. Gülsarı kolhoz tarafindan binek atı olarak istenildiğinde Tanabay bunu reddeder. Ancak bu yaptığının -kolhoza karşı gelişinindoğru bir şey olmadığını karışı Caydar ona şu açıklamayı yaptıktan sonra anlar: "Gülsarı senin kendi malın mı? Kendinin olan, şana özel olan neyin var? Bizde olan her şey kolhoza ait. Bizim halımız, hayatımız böyle. Yorga da kolhozun. Kim yönetiyor bu kolhozu? Başkan. Başkan ne derse o olur. İçindeki kuşkuyu anlamıyor muyum sanıyorsun? Ama boşuna... Onunla ilgisi yok... Karar senin. Ne istersen onu yap" (s. 88). Ayrıca Tanabay dostu Çora ölmek üzereyken gitmek istemediğinde kendisini ikna eden yine Caydar'dır.

\subsection{Karșıt/Hasım Güç Konumundaki Karakterler}

Karşıt güç, "genelde okuyucu tarafından pek sevilmeyen bu kahraman, hemen her firsatta asıl kahramanın karşısına çıkarak onun hedefine ulaşmasını engellemeye çalışır ve onunla çatışmaya girer" (Çetişli, 2004: 70). Karşıt güçteki kişiler bazen egemen güç olarak da görülür. "Bu açıdan bakıldığında egemen güçleri temsil eden yönetici tiplerinin de benzer özelliklere sahip oldukları görülecektir." (Yaşar, 2012b: 245) Bu romanda da asıl kahraman olan Tanabay ve Gülsarı'nın karşısındaki kişiler şunlardır:

İbrahim: Romanda Tanabay'ın sevgili atını kolhoz başkanı Corakul Aldanov'un emri doğrultusunda almasıyla öne çıkar. İbrahim'in Gülsarı'yı almak istemesinin asıl sebebi kendi çıkarı içindir. Yoksa kolhoz ve oradaki işler umurunda değildir. Zaten İbrahim'in Gülsarı'yı aldıktan sonra Kolhoz Başkanı yardımcılı̆̆ına terfi ettirilmesinden de sadece kendi çıkarını düşünen birisi olduğu anlaşılır. İbrahim karşıt güçtür çünkü Gülsarı, İbrahim tarafından iğdiş edilir.

Müfettiş Segizbayev: Segizbayev, Tanabay'ın korada koyun çobanlığ yaptığı bir zamanda teftiş için koraya gider. Tanabay'1, koyunları bilerek öldürmekle suçlar ve kendisini mahkemeye vereceğini söyler. Tanabay'ı yapmadığı hatta aklının ucundan dahi geçirmediği bir şeyle yani kolhoz malına isteyerek zarar veren bir halk düşmanı olmakla suçlar. Bu olaydan sonra Tanabay partiden çıkarılır. 
Kaşkatayev: İlçe merkezi komitesi birinci sekreteri olan Kaşkatayev, Tanabay'ın partiden çıkarılmasına karar veren kişidir.

Aldanov: Çora'nın hastalanması üzerine gelen yeni kolhoz başkanıdır. Son derece acımasızdır. Romanda da "kısa bacaklı, küt, geniş taraklı" şeklinde olumsuz tasvir edilmiştir.

\subsection{Arzu Edilen Kişi:}

Bibican: Romanda arzu edilen, ulaşılmak istenen kişi Bibican'dır. Ona ulaşmak isteyen ise Tanabay'dır. Tanabay romanda evli olmasına rağmen Bibican'la yasak bir aşk yaşar. Bu ilişkiyi kadınlık içgüdüleriyle anlayan Caydar, Tanabay'a yani kocasına sorumluluklarını hatırlattıktan sonra kararı kendisine bırakır. Tanabay karısının sözlerini dinler ve duygularını bir kenara bırakıp mantıklı davranmayı seçer. Böylece savaşta eşini kaybeden, dul bir kadın olan Bibican'la aşkını bitirir. Bibican da Tanabay'dan daha uzak, başka bir yere taşınır.

3.5. Fon Karakter: Roman boyunca çok ön planda olmayan karakterlerdir. Asıl kahraman açısından olumlu özelliklere sahiptir. Hatta bazen asıl kahramanı anlayıp onun düşüncelerine tercüman olur.

Kerimbekov: Romanda Tanabay'ın kolhoz için gerçek bir çalışan olduğunu ve asla bir halk düşmanı olamayacağını söyleyen kişidir. Toplantıda kendisini savunmayan Tanabay'ın savunuculuğunu yapan kişidir.

\section{Mekân}

Romanda mekân, olay veya durumların yaşandığı yerdir. İnsanı merkeze alan bir tür olan mekân bireyin bulunduğu, yaşadığı ve diğer kişiler/varlıklarla etkileşim içine girdiği yer olduğu için kişinin derinliğini ortaya koyabilecek özelliğe sahiptir (Karabulut, Biricik, 2019: 60). Mekân, eserde yaşanan olayların sahnesi olup bireyin hareket alanıyla yakından ilgilidir. "Roman gibi gelişmiş anlatı yapıtlarında mekân, varoluş kaygısıyla ilgili bir duraksamadır; zamanın sonsuz akışında yitip gitmek istemeyen insanın tutunduğu 'dışardaki içerdelik' niteliğinde bir yerdir" (Korkmaz, 2017: 11). Yaşar ise mekân kavramına daha geniş bir çerçevede bakmaktadır: "Bu bağlamda, mekân karakterlerin toplumsal çevrelerini, ruhsal ve kültürel yapılarını betimlemede yazara olanak sağlamaktadır. Her metin, olayları, mekânsal ve zamansal bir çerçeveye yerleştirerek aktarır. Entrik yapı anlatıcı parçalarla belli bir sürenin (durée) içinde geçer; metindeki betimsel parçalar da bu yapıyı mekânla buluşturur. Bu bağlamda roman ve öykü kuramı içinde mekânın önemli bir yeri vardır. Kahramanın eylemlerini kayıt altına alan bir kategoridir. Olay örgüsü, zaman ve kişilerin yanı sıra mekân, tahkiyeli eserlerde kurucu bir öğedir." (Yaşar, 2012a: 38). Bu çerçevede Yaşar'a göre mekân, hem anlatı kişilerinin kimliklerinin, kültürel ve ekonomik durumlarının ortaya konulmasında hem de eylemlerin somutlaştırılması noktasında mekân işlevsel bir özelliğe sahiptir.

4.1. Açık/Geniş Mekânlar: Açık veya geniş mekân hacimsel olmakla beraber özellikle kişilerin psikolojik yapılarıyla da ilgilidir. Roman, hikâye gibi anlatı türlerinde mekânsal açıklık, bireyin huzurlu olduğu, varlığını ortaya koyabildiği algıyla ilgilidir (Karabulut, 2017: 115).

Yayla/Çadır: Romanda yayla Tanabay ve Gülsarı'nın mutlu olduğu hatta tabiatla insanın uyumlu olduğu bir mekândır. Tanabay, Çora'nın isteğiyle yılkıcılık 
yapmak için yaylaya gelir ve Gülsarı'yla da burada karşılaşır. Tanabay ve ailesi keçe çadırda kalırlar. Keçe çadır bir köy kadar büyük olmasa da Tanabay çadırın içine girdiğinde çadır kendisine çok geniş ve büyük bir yer olarak görünür. Ne zaman canı sıkılsa koca dünyanın içinde bu keçe çadıra girer, Caydar da ona kopuz çalar, türküler söyler ve böylece Tanabay can sıkıntısını giderirdi. Çadır, Kırgız göçebe/konar-göçer kültürünün temsilidir. Aslında Tanabay’ın gerçekte geniş bir mekân olan köyde huzur bulamamasına karşılık küçük bir çadırda huzuru bulması ilgi çekicidir. Çadır ayrıca yerleşik düzene bir karşı çıkıştır. Ancak keçe çadır her ne kadar varlı̆̆ını devam ettirmeye çalışmışsa da bu yerleşik düzene, sisteme yenilmekten kendini alamamıştır.

4.2. Kapalı/Dar Mekânlar: Hacimsel olarak kapalı ve dar olma anlamını taşımakla beraber, özellikle kişinin kendini genel olarak huzursuz hissettiği mekânlardır. Kapalı mekânlar, "Romanda dar veya yutucu mekânlar olarak da bilinen kapalı mekânlar kahramanın düşünsel ve ruhsal olarak gelişmesini engeller." (Yaşar, 2017: 30). Romandaki bazı kapalı mekânlar şöyle ifade edilebilir:

Aleksandrovka Yokuşu/Yolu: Roman, bu yol üzerinde Gülsarı'nın ölmek üzere oluşuyla başlar. Tanabay ilçedeki oğlu ve gelinini ziyaret etmek için gidip döndüğü bu yolda geçmişini hatırlar. Romanın hemen tamamı Tanabay'ın Aleksandrovka yokuşu üzerinde geçmişini hatırladığı birkaç saatten ibarettir. Aleksandrovka yolu veya yokuşu olumsuzlukları kendine bağlayan bir mekândır romanda. Çünkü Tanabay o yolda her zaman ya mutsuzdur, ya korkmuştur ya da pişmandır. Yolun olumlu bir yanı olarak belki Tanabay'ın savaş sonrası köye dönerken bu yolu kullanması, bu yoldan geçerken halkı için çalışıp refah seviyelerini yükseltebileceğine inanması ve savaştan sonra güzel şeylerin olacağına inanan bir genç olarak yer alması sayılabilir. Ancak güzel şeylerin olabileceğine inanan bu genç umutlarını, mutlu, güzel şeylere olan inancını bu yolda bırakır. Çünkü tüm umutlarının yerini umutsuzluk, güzel şeylere olan inancının yerini hiç istemeyeceği distopik bir yaşam biçimi almıştır. Tanabay bu yolu, yasak aşkı olan Bibican'ın yanına gitmek için de kullanır. Bunun dışında Tanabay'ın partiden ihracı yine bu yoldan geçer.

Köy/Kolhoz: Savaş sonrası kolektif sistemin temsili olan kolhoz henüz kurulduğunda halkın zenginleşmesini, mutlu yarınları hedefleyen bir sistemdi ancak sistem kurulduktan sonra bu hedeflerin hiçbiri gerçekleşmemiştir. Zenginliğin yerini sefalet, yoksulluk, umudun yerini umutsuzluk almıştır. Kolhozun kendisi köyün içindedir. Köy bu anlamda özgürlüğü değil sorgusuz itaati, zorbalığı, yoksulluğu temsil eder. Tanabay Bibican'dan sonra köye gelmek istemez. Zaten köye ya kolhoz işleri için ya da Bibican için gelirdi. Bibican'la ilişkisini sonlandırdığı için köye olabildiğince az gelmeye çalışıyordu. Tanabay köye her geldiğinde mutsuzdur. Mutsuz olması doğaldır. Çünkü partiden ihracı için düzenlen toplantılar da köyde yapilmaktaydi.

\section{Zaman}

Anlatmaya bağlı türlerde yapı unsurları arasında "zaman"1n da önemli bir yeri vardır. Bir anlatı nasıl ki mekâna ihtiyaç duyarsa zaman kavramına da gereksinim duyar. "Bir romanda hikâye, mutlaka -belirli veya belirsiz- bir zamanda cereyan eder. Yine bu hikâye, belli bir süre sonra öğrenilir/duyulur ve belli bir süre içinde de kaleme alınıp anlatılır. Hal böyle olunca, zaman" unsuru, romanın genel yapısını 
meydana getiren temel elemanlar arasında yer alır. Bir romanı, zamandan soyutlamak mümkün olamaz" (Tekin, 2015: 122-123). Anlatma esasına bağlı türlerden biri olan romanın olmazsa olmazlarından biri de "zaman" mefhumudur. "Elveda Gülsarı, Tanabay ile Gülsarı'nın şahsi maceraları olarak algılanmaya uygun bir roman olduğu kadar, Kırgız ve Kazak Türklerinin aşağı yukarı yirmi yılı aşkın bir süreçteki toplumsal yaşayışlarının aktarımıdır" (Kaplan, 2009: 303). Zaman, romanda iki şekilde yer alır. Birinci zaman dilimi eserin başlangıcında Tanabay'ın Aleksandrovka yokuşunda Gülsarı'nın zayıf düşüp ölünceye kadarki geçmiş günlerini hatırladığı birkaç saatlik zaman dilimidir. İkinci zaman dilimi ise Tanabay'ın II. Dünya Savaşı'nın bitmesinden sonra köye döndüğü zaman dilimidir. II. Dünya Savaşı'nın 1945 tarihinde sona erdiği tarihi kaynaklardan bilinmektedir. Romandaki zamanla ilişkili olarak Tanabay'ın Gülsarı'yı aldığında atın henüz 2 yaşında olduğu bilinmektedir. Bunu Gülsarı'yı Tanabay'a veren yaşlı Turgay'ın şu sözlerinden anlamaktayız: "Geçen yaz kız torunum gelmişti. Bende biraz kaldı. Adını o koydu. Canı gibi sevdi onu. Sarı tay o zaman henüz bir cabağı idi. Unutma adı Gülsarı" (s.25-26). Cabağı, altı aydan bir yaşına gelen at yavrusu için kullanılan bir tabirdir. Buradan hareketle Tanabay'ın romanın başında: “Kaç yaşındasın Gülsarı? Yirmi yaşında mı? Yoksa daha mı fazla. Evet, yirmiden fazla senin yaşın...” (s.19) söylediği bu sözlerden olayların tahmini olarak 1945 ile 1965 yılları arasında yaşandığı söylenebilir.

\section{Bakış Açısı ve Anlatıcı}

Roman, hikâye vb. anlatmaya dayalı türlerde olay veya durumları okuyucuya aktaran kişiye anlatıcı denir. "Sanatçı, anlatımı ne kadar etkili kullanırsa o kadar başarılı bir eser ortaya koyar." (Karabulut, 2020: 35). Anlatıcının olaylara yakınlığı, uzaklığı, hâkimiyeti vb. hususlar da "kahraman, hâkim, müşahit ve çoğulcu" bakış açılarını oluşturur. "Bakış açısı, anlatma esasına bağlı metinlerde vaka zincirlerinin ve bu zincirin meydana gelmesinde kullanılan mekân, zaman, şahıs kadrosu gibi unsurların kim tarafından kime nakledilmekte olduğu sorularına verilen cevaptır" (Aktaş, 2005: 78).

Elveda Gülsarı daha çok müşahit/gözlemci bakış açılı anlatıcıyla kaleme alınmıştır. "Müşahit/gözlemci bakış açılı anlatıcı, itibari dünyada olup bitenleri, sadece müşahede etmekle yetinir. İkinci aşamada da gözlemlerine adeta bir kamera tarafsızlığı ile okuyucuya nakleder. Bu fonksiyonu ile o, itibarı dünyada olup bitenleri okuyucuya aktaran bir "yansıtıcı" konumundadır" (Çetişli, 2004: 87). Bu bakış açısına romanın pek çok yerinde görmek mümkündür:

"Gerçekten de iyi etmemişti. Geç vakitte yola çıkacağına sabahı beklemesi, yola erkenden çıkması gerekirdi. O zaman yolda gelip gidenlere rastlayabilirdi. Oysa Tanabay yola öğleden epeyce sonra çıkmıştı. Bu mevsimde yapılacak iş miydi bu?" (s.14).

"Evet, yorga üyirin arasına girince her şeyi unutuvermişti: kısrak kokusu, kulun kokusu, süt kokusu, pelin kokusu başını döndürüyordu. Onu aramak için peşine düşenlerin yolda olduklarını bilmiyordu elbet" (s. 91).

“Bugün Gülsarı'nın çevresinde niçin bu kadar çok adam vardı? Adamlardan biri boz renkli bir tulum giymiş olanı, parlak madenden bir şeyleri beyaz bir bezin üzerine yerleştiriyordu. Madenler parlıyor, hayvanın gözünü alıyordu. Öteki adamlar 
iplerle Gülsarı'nın çevresini sarmışlardı. Yeni başkan da oradaydı! Kısa bacaklı, küt, geniş taraklı ayaklarını iki yana açmış bir elini beline dayamış, öbür eliyle gömleğinin düğmeleriyle oynayıp duruyor, kabarıyordu. Ötekilerden farklı olarak, o kollarını sıvamıştı" (s. 101).

Romandaki bir diğer bakış açısı ise "tanrısal bakış açısı"dır. 'Tanrısal bakış açısı' (the omniscient point of view) özellikle 'her şeyi bilme' anlayışına dayanır. "Böyle bir imkânla donatılmış (techiz edilmiş) anlatıcı figür, adeta 'Tanrı gibi', her şeyi bilir, görür, sezer; geçmiş̧ten ve gelecekten haberler verir. Kelimenin tam anlamıyla $\mathrm{o}$, her şeyin üstünde ve her şeye hakımdır. Böyle bir güç ve yetenekle donatılmış anlatıcı (the omniscient narrator), aslında gerçek dünyaya ait olan yazara, yarattığ 1 kurmaca (gerçeksi) dünyada yer alan kahramanlarının duygu ve düşüncelerini sunma/anlatma yönünde geniş imkânlar sağlar. $O$, tanrısal konumu (olympian position) itibariyle hem anlatı dünyasındaki karakterleri hem de anlatının dışında kalan okuyucuyu yönlendirebilir. İsterse kahramanların zihinlerine, iç dünyalarına girer, gizli kalmış duygu ve düşünceleri dışa vurabilir” (Tekin, 2015: 57-58).

"Tanabay söylendikçe hırslandı, hırslandıkça da bir ateş bastı ve gömleğinin yakasını çözüp derin derin solumaya başladı. Sonra ne yapacağını bilemeden arabanın çevresini hızlı adımlarla dolandı. Oysa varacağı yer uzak, gece yakın, at bıktın... Bütün bunları unutmuştu o anda. Oğlunun evindeyken gelini ile tartışmamak için kendini tutmuş, ağzını açmamıştı. Ama şimdi patlamıştı. Gelini burada olsa, aklından geçen bütün bu acı sözleri şamar gibi patlatırdı suratına: "Ben partiye kabul eden de sen değilsin, çıkaran da. O zaman işlerin nasıl olup bittiğini sen nereden bileceksin a budala gelin! Şimdi dilin bir karış konuşursun elbet! Okutup adam ettik çünkü sizi! Oysa bizden lâf değil, iş isterlerdi, iş! İş yaparken de babamızı yüzüstü bırakmazdık biz, saygıda kusur etmezdik, babamızın, anamızın, dostumuzun, düşmanımızın, hatta komşumuzun köpeğinin bile yaptıklarından sorumlu tutulurduk. Benim partiden çıkarılmamla ilgili söz söylemek sana düşmez! Bu benim bileceğim iș ha gelincik, sana ne bundan!” (s. 15). Bu sözlerden de anlaşılacağı üzere roman kahramanlarından Tanabay'ın geliniyle ilgili daha önce kimseyle paylaşmadığı düşünceleri hâkim bakış açısının bir özelliği olarak romanda yer almıştır.

\section{SONUÇ}

Cengiz Aytmatov'un eserlerinde dile getirdiği toplumsal sorunlar realiteden bağımsız değildir. Nitekim yazarın anlattığı olaylar tarihe kaydı düşmüş gerçekliklerdir. Elveda Gülsarı'da anlatılan rejim değişikliği, işçi sınıfının sömürülmesi, ekonomideki çapraşıklık, savaşın insanlar üzerindeki etkisi gibi olay ve durumlar arasındaki bağlar mantıksal çerçevede sebep-sonuç ilişkisi içerisinde anlatılmışıı. Cengiz Aytnatov bu anlamda hayatını etkileyen olay ve durumları eserlerine yansıtmıştır. Elveda Gülsarı ekonomik, toplumsal olayları anlatmasının yanında gerçek bir dostluk hikâyesini de anlatan bir romandır. Romandaki yaşlı Tanabay ve yaşlı at Gülsarı arasındaki ilişki incelendiği için bu durum daha iyi anlaşılmıştır. Cengiz Aytmatov diğer birçok romanına ideolojik yaklaştığı gibi bu romanına da ideolojik bir yaklaşımla nüfuz etmiştir. Her ne kadar bu romanda üstü örtülü olarak verilen ideolojik meseleler varsa da bu Aytmatov'un bilinçli olarak yaptığı bir davranış olarak değerlendirilmelidir. Yazar bu eseriyle savaş sonrası 
toplumun panoramik bir fotoğrafını vermiştir. Bu çalışmada Elveda Gülsarı adlı roman, roman tekniği bakımından incelendi. Roman; olay örgüsü, konu ve tematik düzlem, kişiler, mekân, zaman ve bakış açısı ve anlatıcı gibi roman unsurları bakımından ele alındı.

\section{KAYNAKÇA}

Akça, Netice Uray (2017), Cengiz Aytmatov'un Romanlarında Tipler, Yüksek Lisans Tezi, Adnan Menderes Üniversitesi: Aydın.

Aktaş, Şerif (2005), Roman Sanatı ve Roman Incelemesine Giriş, Ankara: Akçağ Yayınları.

Alpaslan, Gonca Gökalp (2014), Cengiz Aytmatov'un Elveda Gülsarı, Dişi Kurdun Rüyaları Ebedi Gelin: Dă̆lar Yıkıldı ğı Zaman Romanlarında Hayvan Zihni, TÜBAR Dergisi, 14.

Aylanç, Mihrican (2010), Cengiz Aytmatov'un Öykü ve Romanlarında Savaş Karşıtllğ̆, Cengiz Aytmatov: Tematik Incelemeler, (Ed. Orhan Söylemez), Ankara: Atatürk Kültür Merkezi Yayını.

Aytmatov, Cengiz (2019), Elveda Gülsarl, İstanbul: Ötüken Yayınları.

Çetişli, İsmail (2004), Metin Tahlillerine Giriş/2, Ankara: Akçağ Yayınları. Yayınları.

Ercilasun, Bilge (2013), Türk Roman ve Hikâyesi Üzerine, İstanbul: Dergâh

Kaplan, Ramazan (2009), Elveda Gülsarı Romanında Insanların Dünyast. Ankara: Kültür ve Turizm Bakanlığ 1 Yayınları.

Karabulut, Mustafa (2017), Halide Edip Adlvar'ın "Sinekli Bakkal" Romanında Mekân, Romanda Mekân (Editörler: Ramazan Korkmaz, Veysel Şahin), Ankara: Akçă̆ Yayınları.

Karabulut, Mustafa, Güvenç, İpek (2018), Roman Tekniği Bakımından Tahsin Yücel'in 'Yalan' Romanı, Çukurova Üniversitesi Türkoloji Araştırmaları Dergisi, 114.

Karabulut, Mustafa, Biricik, İbrahim (2019), Sabahattin Ali'nin “Kuyucakl Yusuf" Romanında Mekânın Poetiği, Journal of Turkish Language and Literature, Volume:5, Issue:1, Winter 2019, 56-70.

Karabulut, Mustafa (2020), "Araba Sevdası” Romanında Bakış Açısı Ve Alatıcı Düzlemi, Romanda Bakış Açısı ve Anlatıcı Düzlemi, (Editör: Veysel Şahin), Ankara: Akçağ Yayınları.

Korkmaz, Ramazan (2014), Aytmatov Anlatılarında Ötekileşme Sorunu ve Dönüş İzlekleri, Ankara: Garafiker Yayınları.

Korkmaz, Ramazan (2017). Romanda Mekânın Poetiği, Romanda Mekân (Editörler: Ramazan Korkmaz, Veysel Şahin), Ankara: Akçağ Yayınları.

Söylemez, Orhan (2010), Cengiz Aytmatov: Tematik Incelemeler, Ankara: Atatürk Kültür Merkezi Yayını.

Tekin, Mehmet (2015), Roman Sanatı, İstanbul: Ötüken Neşriyat. 
Tural, S. Kemal (2009), Filozof, Şair, Romancı Yüzyılımızın Yeni Velisi, Cengiz Aytmatov, Ankara: Kültür ve Turizm Bakanlığı Yayınları.

Yaşar, Hüseyin (2013), Nesl-i Ahir'de Bir Meşrutiyet Aydını: Süleyman Nüzhet, TÜBAR-XXXIII-/ 2013-Bahar, 283-309, Ankara.

Yaşar, Hüseyin (2012b), Guy de Maupassant'ın "Sicim”inden Refik Halit'in “Vehbi Efendi'nin Kuşkusu”na İzler, Hacettepe Üniversitesi Türkiyat Araştırmaları Dergisi, 2012 Bahar (16), 233-256, Ankara.

Yaşar, Hüseyin (2012a), Ahmet Ümit'in Beyoğlu Rapsodisi'nde Mekân Olarak "Beyoğlu”, Ç.Ü. Sosyal Bilimler Enstitüsü Dergisi, Cilt 21, Say1 2, 2012, 37-58, Adana.

Yaşar, Hüseyin (2017), Bir Gençlik Romanı: Her Gece Bodrum Romanında Mekânın İşlevi, SOBIDER, Sosyal Bilimler Dergisi / The Journal of Social Science / Y1l: 4, Say1: 18, Aralık 2017, 23-34, Malatya.

Yaşar, Hüseyin (2008), Yeni Roman'da Kahraman ve Olay Örgüsü'nün Aldı̆̆ Yeni Biçimler, Sosyal Bilimler Araştırma Dergisi, SBArD, S. 11, Mart 2008, 89-97, Diyarbakır. 